\title{
ASSESSING THE METHODOLOGICAL DIFFERENCES BETWEEN BRAZILIAN JOURNALS AND TOP JOURNALS IN STRATEGY
}

\author{
RONEI DA S. LEONEL ${ }^{1}$ \\ (iD) https://orcid.org/0000-0002-6406-0112 \\ SARA F. PICHETH ${ }^{2}$ \\ (iD) https://orcid.org/0000-0002-4081-731X \\ FERNANDA R. DA SILVA \\ (iD) https://orcid.org/0000-0001-6753-3125 \\ JOÃO M. CRUBELLATE \\ (iD) https://orcid.org/0000-0003-1446-8248
}

To cite this paper: Leonel, R. S., Picheth, S. F., Silva, F. S., \& Crubellate, J. M. (2018). Assessing the methodological differences between Brazilian journals and top journals in strategy. Revista de Administração Mackenzie, 19(3). doi:10.1590/1678-6971/eRAMR180009

Submission: Jan. 22, 2018. Acceptance: Apr. 11, 2018.

1 University of Memphis, Memphis, TN, United States.

2 Universidade Estadual de Maringá, Maringá, PR, Brazil.

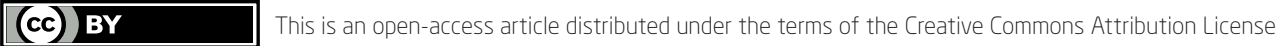

\footnotetext{
This paper may be copied, distributed, displayed, transmitted or adapted if provided, in a clear and explicit way, the name of the journal, the edition, the year and the pages on which the paper was originally published, but not suggesting that RAM endorses paper reuse. This licensing term should be made explicit in cases of reuse or distribution to third parties. It is not allowed the use for commercial purposes.

Este artigo pode ser copiado, distribuído, exibido, transmitido ou adaptado desde que citados, de forma clara e explícita, o nome da revista, a edição, o ano e as páginas nas quais o artigo foi publicado originalmente, mas sem sugerir que a RAM endosse a reutilização do artigo. Esse termo de licenciamento deve ser explicitado para os casos de reutilização ou distribuição para terceiros. Não é permitido o uso para fins comerciais.
} 


\section{ABSTRACT}

Purpose: Our study compares methodological procedures of Brazilian papers with those of papers published in AMJ, OS, ASQ JMS and SMJ in field of strategy from 2006 to 2015.

Originality/value: Our study 1. identifies and describes methodological differences, offering a benchmark to improve future studies; 2 . starts a discussion about the reasons those differences exist and their implications towards advancing the field of strategy; and 3. suggests forms of overcoming the current constraints and improving the quality of our research.

Design/methodology/approach: Based on a systematic review, we analyzed ten Brazilian journals with the highest impact factor and five top journals. The search yielded a final sample of 1294 empirical papers. The data was analyzed through content analysis, for which our coding schema contained three dimensions: research design, measurement, and analytic approach.

Findings: We found some methodological differences that may characterize Brazilian papers as testers and top journals as expanders, reinforcing results found by other studies, concerning the necessity of developing the Brazilian strategy field to be more competitive with the international field at large. Therefore, we concluded that it is desirable to improve our research methods as a field and possibly to overcome methodological differences, helping not only to develop theories but also to consider the Brazilian reality.

\section{KEYWORDS}

Research methods. Quantitative. Qualitative. Data analysis. Strategy field. 


\section{INTRODUCTION}

The discussion about the quality of academic publication in Brazil has been a constant in the last decades. First, the systematic reviews have enlightened our comprehension on theoretical models driving the research in Brazil from organizational studies (Vergara \& Carvalho Jr., 1995) to finance (Leal, Oliveira, \& Soluri, 2003) to marketing (Vieira, 2003), and has shown our balance between theoretical and empirical papers. Second, network analyses of co-authors have shown the evolution and the configuration of research teams (Rossoni \& Guarido Filho, 2007, 2009). Currently, the search for internationalization has pushed researchers to compete not only with Brazilian peers but also with international peers for space in journals in which acceptance rates can reach only ten percent. Given the new competitive setting, we understand that it is time to reflect on the profile and quality of research methods in Brazil.

Although proper methodological procedures are not enough to guarantee publication, problems in those aspects lead to paper rejection (Bergh, 2003; Aguinis \& Vanderbeg, 2014; Bono \& McNamara, 2011). Likewise, methods constrain the capacity of developing and convincing theoretical contributions, and consequently the advance of field (Zhang \& Shaw, 2012). Having this in mind, the strategy field is one that has been recognized as an increasingly important field of knowledge (Schneider, 2013; Guerras-Martín, Madhok, \& Montoro-Sánchez, 2014) with intense increase in the volume of publications. However, it has also dealt with a lack of adequate methodology to sustain the generation and advancement of knowledge along its expansion (Ketchen Jr., Boyd, \& Bergh, 2008).

To our knowledge, methodological reflections in the strategy field in Brazil have been limited 1. to compare papers with the methodology literature (Oliveira et al., 2012) or 2. to summarize the methods used in papers (Rossoni, Guarido Filho, Francisconi, \& Albuquerque Filho, 2010). Although the definition of the best research method based on research problem is effortless, lack of resources and barriers to access primary or secondary data constrain the implementation of research, resulting only in satisfactory procedures. Because of the rationale behind the implementation of research methods, the current reviews have limitations. First, while assessing methodology with literature shows how far we are from ideal types, it offers no concrete parameter of comparison. Second, the simple summarization of literature gives no comparative standard and guide to the improvement of research methods. 
Unlike previous studies, our study adopts an intermediary position between ideal method and simple summarization. To identify the profile and the quality of research methods in Brazilian research, we compared Brazilian papers to papers published in five top journals, a feasible standard of research method that also suffered constraint. We gathered the Brazilian papers from the ten most influential Brazilian journals using the five-year impact factor without auto citation, published by Scientific Periodicals Electronic Library (SPELL) in 2014. We recognize that Brazilian scholars not only do not publish only in Brazilian journal but also have incentives to try to publish their best papers in international journals. As an anonymous reviewer noted, these factors could bias our sample. However, the frequency in which Brazilian scholars published internationally during the period of our time frame is very small. Thus, our sample has a small bias and, consequently, represents a valid proxy of overall quality of Brazilian research (see appendix A for a full explanation of the additional analyses performed to assess the potential bias). Our study also differs from past studies because it uses only Brazilian papers published in peer-reviewed journals. Although in the past conference papers had more relevance, the maturation of the field allows us to rely only on peer-reviewed papers. Selecting journal papers represents an improvement in terms of quality because editors and the double blind peer-review process push authors to refine methodological procedures, fixing possible flaws. Finally, we offer a current overview of the last decade which includes the emergence of the internationalization as issue in Brazilian academia and an increase in the investment received by master and doctoral programs and in post-doctoral training.

Assessing the methodological differences between Brazilian papers and top journals papers in the field of strategy from 2006 to 2015, our study makes multiple contributions. First, it identifies and describes the methodological differences, offering strategy researchers a benchmark to improve future studies. Second, it starts a discussion about reasons those differences exist and implications towards advancing the field of strategy. Third, the study offers suggestions for overcoming current constraints and improving the quality of our research. Fourth, it can help Brazilian journals advance their quality standards and their potential of internationalization.

We organize the study in five sections. Following this introduction, the theoretical background reviews previous evaluation of the strategy field in Brazil. The methodological procedures section describes the process of building the corpus and coding procedures. The results and discussion section discuss the difference between papers in Brazilian journals and 
papers in top journals in terms of distribution of overall design and in profile of quantitative and qualitative methods. Finally, the conclusion section presents implications and some possible solutions to the problems identified in the analyses.

\section{THEORETICAL BACKGROUND}

Given its importance to explain success and failure of firms and organizations in general, strategy is an important field of knowledge (Schneider, 2013; Guerras-Martín et al., 2014; Schneider, Carneiro, Serra, Ferreira, \& 2009). Identifying the sources of organizational effectiveness and success (Guerras-Martín et al., 2014), creating and maintaining competitive advantages, and conducting organizational changes (Schneider et al., 2009) are some of core objectives in strategy research.

Despite its importance in the education and practice of management, the systematization of the knowledge in strategy only happened after the consolidation of other functional disciplines (Bertero, Vasconcelos, \& Binder, 2003). In fact, it has been developed as a social science field of knowledge in the last 50 years, what means that it is still in the process of consolidation (Bertero et al., 2003; Ketchen Jr. et al., 2008; Guerras-Martín et al., 2014). According to Guerras-Martín et al. (2014), the study of strategy began in the 60's with the seminal studies of Chandler (1962), Ansoff (1965) and Andrews (1971). Since then, the evolution of the field has benefitted from contributions of different social sciences, with diversification of topics and research methods, even though strategy has retained its core.

In the same way, in Brazil, the interest in studying strategy has increased in the last decades. It can be perceived by significant growth in the volume of academic publications in strategy, by the number of researchers working in this field, and by the intensification of the ties of co-authorship among researchers (Saraiva \& Carrieri, 2009; Rossoni et al., 2010; Walter, Bach, Lanza, \& Sato, 2013; Guerras-Martín et al., 2014). Such increase also reflects other aspects as the growth of the number of graduates and the rigor of those programs, and of Brazilian governmental institutions for better results (Saraiva \& Carrieri, 2009). In the same vein, the creation of thematic tracks in the Brazilian meeting of research in management and the creation of the 3Es, a Brazilian meeting of studies in strategy contributed to expand the research in strategy in the country (Rossoni et al., 2010). Regarding the general content of the Brazilian research on strategy, it is a 
tendency to select problems and other aspects that better express the strategic reality of national firms. That tendency results in a focus on processes of organizational adaptation and change as a major topic in the study of strategic management of our national firms (Bertero et al., 2003).

In the 1960's and in the beginning of the 1970's, strategy approaches were more general and laid the groundwork for subsequent theorization in the field of strategy. Thereupon, strategy was taken as a problem that concerns the type and quality of the response of firms and organizations in face of environmental pressures, focusing on internal and external aspects of that relation. Although over time theories have highlighted one or another of these aspects, both have been recognized as important and have never been dismissed by the most relevant papers. Thus, it shows the complexity of the phenomenon of strategy, and reflects the evolution of strategy as an academic discipline and as an effort to comprehend the relationships between organizations and environments, two different but intertwined domains. The same is valid regarding the tension between micro and macro levels (Guerras-Martín et al., 2014).

However, Mahoney and McGahany (2006) assert that strategic management research suffers criticisms from root disciplines such as economics, sociology and organizational theory for lacking theoretic grounding and for dissociation of the real problems of business strategy. Similarly, Schneider (2013), after analyzing the evolution of the study of strategy in the last decades of the twentieth century and the first decade of the twentieth-first century, concluded that its academic field is still too broad, without a clear definition of its main themes. This results in a multitude of perspectives, debates and controversies among authors.

Durand, Grant, and Madsen (2017) present a contrasting vision about the intense and recent development of the field of strategic management. On the one hand, there are authors who criticize the fragmentation of the field, its lack of accuracy in the theoretic effort, among other problems. On the other hand, there are authors who admit as positive the theoretic pluralism and even the methodological pluralism of the field as a source of new ideas. In both cases, however, there is a clear consensus on the necessity of continually updating the research effort, both in terms of theory and methodology.

To Guerras-Martín et al. (2014) one of the important reasons for the reception of too many theoretical and methodological perspectives in strategy is the interest for understanding the bases of competitive advantages in firms and organizations. In view of this, Mahoney and McGahany (2006) 
argue that the strategy field must focus on some critical aspects in order to get maturity as a field of knowledge. Among these, they highlight the development of new integrative theory, based on insights empirically validated and accumulated during the last years. Additionally, such integration must also include theories and methods of research that enable one to deepen important questions in the field and show comprehensiveness and accuracy in handling empirical data (Mahoney \& McGahany, 2006; Guerras-Martín et al., 2014).

Consequently, a way to analyze and become aware of the possibilities of development of the strategy field comes from mapping the field. Some aspects of the evolution of the field, in the last decades, make clear that some maturity has been achieved which can be made evident in the analytical capacity and methodological accuracy, despite the limits pointed out before. Such indicators as new theoretical directions in the field and the emergence of new and important topics of investigation increase consensus to basic notions, growth of the research methods used and improvement of their sophistication, and growth of the academic community dedicated to the field according to Guerras-Martín et al. (2014). The present growth of the strategy field suggests the necessity of comparing scientific publication as a way and resource to establish the present limits of the field and to know its possibilities of evolution (Rossoni et al., 2010).

Thus, the analysis of publications in an academic field is an important device frequently used to evaluate its development, to compare with development in other fields and to throw light on its present limitations and future possibilities (Saraiva \& Carrieri, 2009; Rossoni et al., 2010). Brazilian researchers have performed review studies in strategy, mainly after the year 2000, but studies which focus on methodological procedures are still rare. At the same time, the major focus of these Brazilian reviews has been of papers presented in meetings, with predominance of the Meeting of the Brazilian Association of Post-Graduation in Management (Enanpad) (Rossoni et al., 2010; Oliveira et al., 2012; Kühl \& Kühl, 2011; Walter et al., 2013). Oliveira et al. (2012), for example, studied how validation criteria are employed in papers on strategy presented at Enanpad. Kühl and Kühl (2011), based on the same source of papers, investigated how technology is embedded in the studies of the strategy field. Walter et al. (2013) have studied co-authoring networks developed from Brazilian researchers in the field of strategy. They also used, as a source of empirical data, papers presented at Enanpad and 3Es. Rossoni et al. (2010) evaluated quantitatively and qualitatively the methodological framework of papers. They conclude 
that Brazilian papers in strategy do not take into consideration other national research and lack theoretical contributions. Thereby, papers depend excessively on foreign references. Schneider et al. (2009) found similar results. They emphasize that the Anglo-Saxon context has strongly influenced the Brazilian research on strategy. It is a case of asking whether the influence also extends to other aspects of research, for example, the proper application of methodological procedures, statistical techniques and conceptual accuracy, or is limited to themes? This is the relevant question we try to answer with our research.

In relation to the methodological aspects of Brazilian papers in strategy, Rossoni et al. (2010) have concluded that many papers inappropriately use some methodological procedures and techniques. For authors, there are some problems that allow one to put under suspicion the real development and maturity of the field of strategy in Brazil. One of these problems is the predominance of case studies in qualitative research. What is even worst when the cases are taken as exemplification of a phenomenon and not as source of evidence. Another identified problem is the low number of studies based on multi-methods for analyzing data and the low effort applied to theoretical papers. The same problems were also pointed out by Bertero et al. (2003), without repercussion in the field.

In this paper we acknowledge that the method is a crucial attribute for scientific knowledge. As Ketchen Jr. et al. (2008) suggested, some of the first studies in strategy had durable impact on the field due to their methodological framework. Moreover, they argue that from the 1980's, with the intense increase in the volume of papers published, the strategy field experienced a theoretical rebirth demanding new methodological perspectives to sustain the generation of knowledge. Additionally, a central problem in the strategy field is the lack of adequate methods to depict and understand the process of implementation and execution of strategies. The persistence of this problem will limit the conditions for generating good insights and the transfer of knowledge to management practice (Ketchen Jr. et al., 2008).

Although research methods play a key role in the advancement of the field - because empirical data provide support and questions, and help expand theoretical arguments - they have been neglected many times in strategy research (Ketchen Jr. et al., 2008). Additionally, the intense growth of a field and its consequent aim of progress and maturation demands that scholars employ proper methodology that provides safe and well-directed advancement. The expansion of theoretical approaches and of adequate methods provides 
the foundation for the strategy field to deal with the challenge of producing knowledge that translates the multifaceted and complex character of organizational phenomenon (Mahoney \& McGahany, 2006).

\section{METHODOLOGICAL PROCEDURES}

Given our intent to compare Brazilian papers with papers published in five top journals in the field of strategy, we used the five-year impact factor without auto-citation calculated by Scientific Periodicals Electronic Library (SPELL) and published in 2014 to identify ten Brazilian management journals with the largest impact factor. We used the SPELL impact factor rather than Qualis Capes because whereas the former offers a clear ordinal rank of Brazilian journals, the latter has no criteria for distinguishing journals inside a category and to define their impact in other Brazilian journals. Additionally, we elected to not use the auto-citation five-year impact factor because auto-citation inflates the impact factor and misrepresents the influence of journal. Unlike other studies, our study did not sample conference annals. While conference annals have no negative impact in topic analysis, in our analysis it could impact significance. The double-blind review process filters the quality of papers published, offering a better estimate of overall quality of Brazilian papers.

The Brazilian journals selected were Brazilian Administrative Review, Cadernos Ebape, Organização e Sociedade, Revista de Administração Contemporânea, Revista Administração Empresas, Revista de Administração Pública, Revista de Administração da USP, Revista de Administração Mackenzie, Revista de Administração da UFSM and Revista de Contabilidade e Finanças. In addition, we selected Academy of Management Journal, Administrative Science Quarterly, Strategic Management Journal, Journal of Management Studies and Organization Science because they are considered "A+" journals in the strategy field by virtue of acceptance rate, influence and contributions to field. Finally, we defined the period from 2006 to 2015 as time frame because prior this period the most part of Brazilian papers ended in conference annals.

In each journal, we searched in title, abstract and keywords for the following terms: strategy, strategic management, resource-based view, dynamic capabilities, transaction costs, institutional strategy and strategic. In Strategic Management Journal, we decided to gather all papers rather than use the key terms to filter articles because it represents a leading journal in the strategy field. The terms capture a broad range of theories and 
perspectives aligned with strategic phenomena (Ronda-Pupo \& GuerrasMartin, 2012). The search retrieved 1,620 papers, 1,289 came from top journals and 331 came from Brazilian journals. From total, 20\% percent were theoretical papers. Thus, our final sample consisted of 1,294 empirical papers, 1,038 articles (80\%) from top journals and 256 articles (20\%) from Brazilian journals.

To analyze the data, we undertook content analysis, which is considered an appropriate method for review studies (Duriau, Reger, \& Pfarrer, 2007). We read and coded the method sections of all empirical papers. Figure 3.1 illustrates the scheme used to code our sample. Following previous methodological studies (e.g., Aguinis, Pierce, Bosco, \& Muslin, 2009; Ketchen Jr. et al., 2008; Scandura \& Williams, 2000; Cools, Armstrong, \& Verbrigghe, 2014), our coding schema contained three dimensions: research design, construct measurement, and analytic approach. First, in terms of research design, we coded six aspects: the overall design, research strategy, sample size, time frame, number of data sources, and data source. Second, in relation to construct measurement, we coded how the constructs were validated through five aspects: exploratory factor analysis, confirmatory factor analysis, reliability test, common method variance, and other types. Finally, regarding the data analysis approach, we investigated the level of analysis and the type of analysis by differentiating between quantitative and qualitative techniques. Three authors who have completed research methods and statistics courses coded all papers retrieved using spreadsheet software to support the coding process. Finally, given that our variables are nonmetric, we performed a chi-square test of independence, a nonparametric test, to assess the association between two categorical variables. 


\section{(Figure 3.1)}

\section{CODING SCHEMA OF PAPERS PUBLISHED IN STRATEGY}

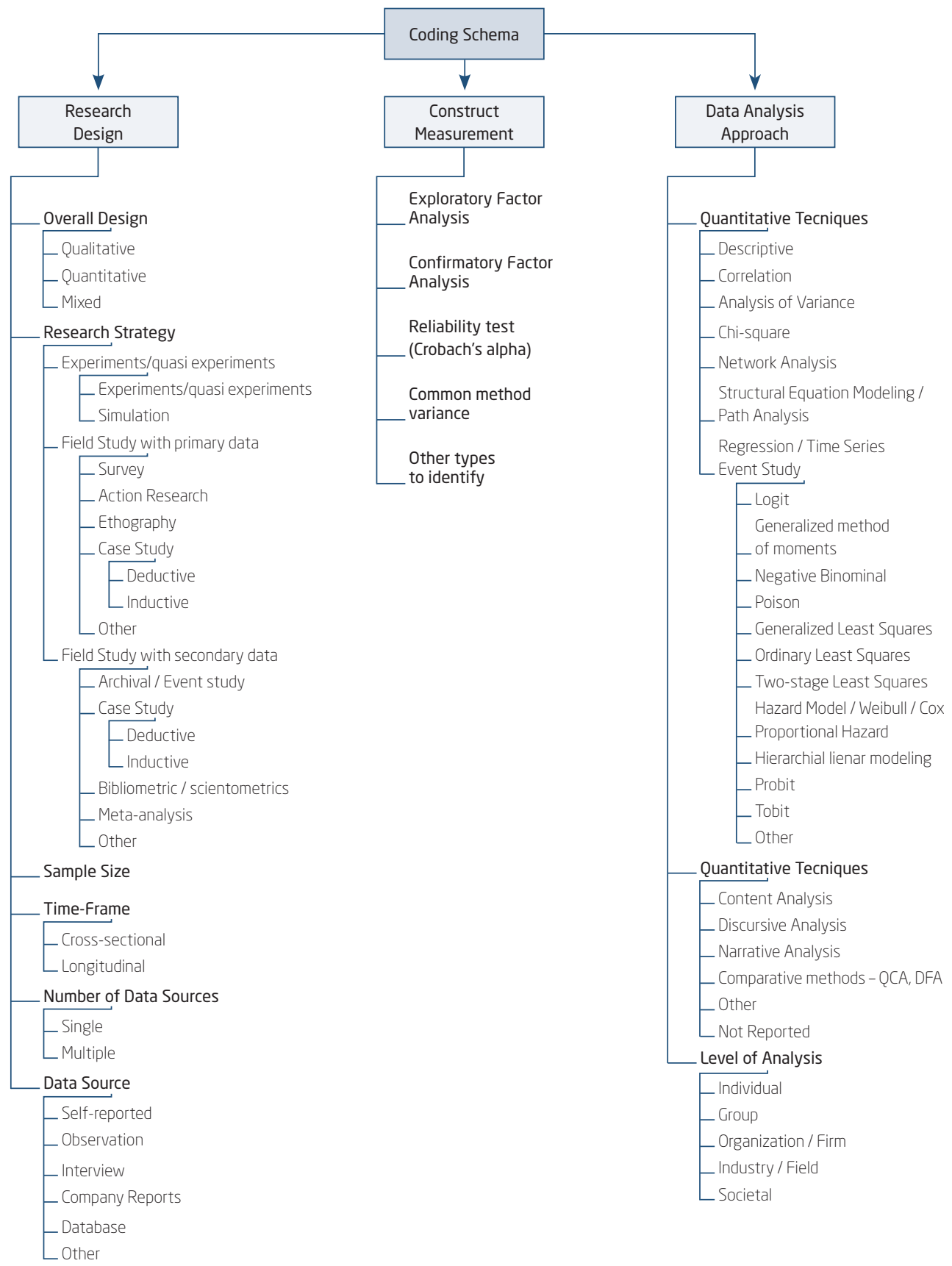

Source: Elaborated by the authors. 


\section{RESULTS AND DISCUSSIONS}

The research method utilized in a project is a central piece of scientific endeavors because it represents the tools that distinguish the knowledge produced by researchers, academia in general, from everyday knowledge. However, selecting a method implies how we see, how we collect and how we analyze the data. Consequently, it affects our capacity to have a dialog with previous and future research and can hide a genuine great idea to advance knowledge within the field. Given such importance, we compare methodological procedures of Brazilian papers with papers published in five top journals in the field of strategy.

In Figure 4.1, we summarized overall research design, time frame and the level of analysis of the 1,294 empirical papers analyzed. A chi-square test of independence was performed to examine the relationship between overall design between Brazilian journals and top-five journals. The relationship between these variables was statistically significant, $\chi^{2}=(2, N=1294)=$ 370.282, $\mathrm{p}<.001$. Effect size, measured by Cramer's V, was .541, which is considered to be a large effect size. This means that between Brazilian journals and top-five journals there is a difference in the proportion of each overall research design. While in Brazilian journals qualitative research accounted for a large proportion of research published, $44 \%$ and $55 \%$ respectively, in top journals quantitative research represented the dominant approach, $90 \%$ and $89 \%$ respectively. The predominance of qualitative methods over quantitative methods, in Brazilian journals, can be explained by the difficulty of gathering data. These findings reinforce a pattern already discussed, that may express a fragility and immaturity of the research field (Rossoni et al., 2010; Bertero et al., 2003).

For instance, whereas the mean of the sample in quantitative studies in Brazilian papers is 196 cases, the mean of the sample in top journals papers is 11,234 cases, which is 50 times higher. Additionally, the lack of access to databases such as Compustat or services such as Wharton Research Data Services, which facilitates the process of gathering data to analyze, may induce the Brazilian researcher to choose qualitative research. Yet the process of collecting data from databases is not as straightforward and easy as one may normally think. It requires retrieving and matching cases from different sources, finding new sources or using the data in different ways. Hence, the difficulty of building a valid sample should not be considered an obstacle to conduct quantitative research in Brazil. We will revisit this 
discussion posteriorly when we discuss the different profiles of quantitative research. A second reason for the predominance of qualitative researchers can be explained by the better fit to Brazilian journals. For instance, a quantitative paper showing no relationship between two variables that were related in a developed country has less impact than a qualitative paper describing how a theoretical relationship changed in Brazil.

To test our phenomenon, we performed a chi-square test of independence to examine the relationship between time frame of research with Brazilian journals and top five journals. The relationship between these variables was statistically significant, $\chi^{2}=(1, N=1234)=73.320, \mathrm{p}<.001$. The effect size, measured by Phi, was .244; which means a medium effect size. Given that qualitative research methods rely on primary data, we expected the emphasis to be on cross-sectional time frame instead of longitudinal research. Furthermore, another plausible explanation is that the pressure to publish and the process of evaluation of graduate programs in Brazil bias the conceptualization of research. Additionally, the short period that academics have to complete their master's and Ph.D. degrees makes it more difficult to dedicate oneself properly to longitudinal research. In a North American context, a Ph.D. student has a financial limitation - funding of four years, for example, but not a time constrain of 48 months as Brazilian students have. The chi-square test of independence performed to examine the distribution of level of analysis was statistically significant $\chi^{2}=(5, N=1270)=44.318$, $p<.001$. The effect size, measured by Cramer's V, was .187, a medium effect size. While Brazilian papers have few studies at the multilevel and individual level of analysis, those in top journals have few at the societal level.

\section{(Figure 4.1)}

\section{SUMMARY OF EMPIRICAL PAPERS IN STRATEGY}

\begin{tabular}{lllll}
\hline & \multicolumn{2}{c}{ Brazilian Journals } & \multicolumn{2}{c}{ Top Journals } \\
\cline { 2 - 5 } & $2006-2010$ & $2011-2015$ & $2006-2010$ & $2011-2015$ \\
\hline Overall design & & & & \\
\hline Quantitative & $39(37 \%)$ & $47(33 \%)$ & $405(90 \%)$ & $519(89 \%)$ \\
\hline Qualitative & $47(44 \%)$ & $79(55 \%)$ & $31(7 \%)$ & $52(9 \%)$ \\
\hline Mixed & $19(18 \%)$ & $17(12 \%)$ & $13(3 \%)$ & $12(2 \%)$ \\
\hline
\end{tabular}




\section{(Figure 4.1 (conclusion) )}

SUMMARY OF EMPIRICAL PAPERS IN STRATEGY

\begin{tabular}{lllll}
\hline & \multicolumn{2}{c}{ Brazilian Journals } & \multicolumn{2}{c}{ Top Journals } \\
\cline { 2 - 5 } & $2006-2010$ & $2011-2015$ & $2006-2010$ & $2011-2015$ \\
\hline Time Frame & & & \\
\hline Cross-sectional & $93(85 \%)$ & $120(80 \%)$ & $227(50.5 \%)$ & $242(41 \%)$ \\
\hline Longitudinal & $15(13 \%)$ & $28(18 \%)$ & $226(49.5 \%)$ & $343(59 \%)$ \\
\hline Level of Analysis & & & & \\
\hline Individual & $2(2 \%)$ & $1(1 \%)$ & $23(5 \%)$ & $53(9 \%)$ \\
\hline Group & $0(0 \%)$ & $4(3 \%)$ & $9(2 \%)$ & $9(2 \%)$ \\
\hline Organizational & $85(79 \%)$ & $116(78 \%)$ & $361(80 \%)$ & $462(79 \%)$ \\
\hline Industry/Field & $9(8 \%)$ & $10(7 \%)$ & $29(6 \%)$ & $27(5 \%)$ \\
\hline Society & $7(7 \%)$ & $11(7 \%)$ & $8(2 \%)$ & $7(1 \%)$ \\
\hline Multilevel & $1(1 \%)$ & $1(1 \%)$ & $15(3 \%)$ & $19(3 \%)$ \\
\hline Not applied & $3(3 \%)$ & $5(3 \%)$ & $8(2 \%)$ & $8(1 \%)$ \\
\hline
\end{tabular}

Source: Elaborated by the authors.

To verify the overall methodological differences, we evaluated whether the quantitative and qualitative research differ on research strategy, number and kind of source and data analysis techniques. Figure 4.2 summarizes the information on quantitative methods, and Figure 4.3 does the same for qualitative methods. Assessing research design in quantitative papers, we identified that papers in Brazilian journals used survey predominantly $(61 \%$ of papers in both periods) whereas papers in top journals utilized archival/ event studies as the main research design. The chi-square test of independence to examine this difference was statistically significant $\chi^{2}=(2, N=1014)=$ $54.124, p<.001$ and the effect size, measured by Cramer's V was .231, a medium effect size. The difference holds even if we test the periods separately. For the period of 2006 to 2010 , the $\chi^{2}=(2, N=446)=15.825, p<.001$, and effect size was .188. For the second period of 2011 to $2015, \chi^{2}=(2, N=568)=$ $41,352 p<.001$ and the effect size was .270 . This represents that the gap between papers in the five top journals and papers in Brazilian journals is not closing. In actuality, it is expanding. This interpretation is strengthened when we compare whether quantitative research design inside a category of 
paper differs from period 1 to period 2. While the chi-square test of independence for papers in five top journals was significant $\chi^{2}=(2, N=928)=$ $15.456 p<.001$, with an effect size of .129, it was not as strong for papers in Brazilian journals, though it was still significant at $\chi^{2}=(2, N=86)=000$ $p<.001$, and had an effect size of .002 . This signals that the lack of maturation described by Rossoni et al. (2010) persists in the study of strategy in Brazil. As an anonymous reviewer noted, one possible alternative explanation could be the fact that Brazilian scholars have tried to internationalize more of their publications. Therefore, they sent their best paper to a foreign journal and papers with lower quality to Brazilian journals. However, in our time frame this tendency is not accentuated, so the probability that this tendency explains all the change is low (see appendix one for the full explanation about the internationalization tendency).

The use of survey and self-reported data presents limitations in terms of information and theoretical problems addressed, and increases the threat to validity (Green, Tonidandel, \& Cortina, 2016). First, organizations are widely recognized by having low engagement in surveys. Baruch and Holtom (2008) identified that the average response rate in studies at the organizational level was $37 \%$, which was $12 \%$ less than that of studies at the individual level. Additionally, surve y requires the elaboration of scales that need to be developed and purified before the study. Social desirability, questionnaire length, mood, reliability and construct validity are all possible threats to such study (e.g., Clark \& Watson, 1995; Mackenzie, Podsakoff, \& Podsakoff, 2011 to discussion on each point). Another threat to validity is common method bias (CMB). CMB posits that the correlation found among variables was not due to an empirical relationship but due to sharing a same source of data (Podsakoff, MacKenzie, Lee, \& Podsakoff, 2003). Analyzing editor and reviewers' letters of Journal of Business and Psychology, Green et al. (2016) suggested that if editors and reviewers found CMB issues in the study, they will likely reject the manuscript. To overcome this problem, the researcher should collect the data for the predictor (independent) variable and the outcome (dependent) variable from two different sources or, at least, calculate Harman's one-factor test to evaluate whether data relies on more than one factor. The practice of using different sources or calculating Harman's one-factor test is well established in the five top journals with papers assessing and discussing the threat of common method bias. As Green et al. (2016) noted, there are better statistical remedies to CMB such as those described by Podsakoff et al (2003), Conway and Lance (2010), and Johnson, Rosen, and Djurdjevic (2011). However, such patterns have little 
resemblance to Brazilian papers, in which $75 \%$ of papers rely on a single source for data, and in fact only one paper discussed the result of Harman' s one-factor test.

Another underperforming point in Brazilian papers is the fact that around $12 \%$ of quantitative papers used descriptive statistics and correlations as the main statistical technique. Both are basic procedures used primarily to describe the characteristic of data. Furthermore, most regression studies rely on ordinary least squares as model of fit. It reflects the limited scope of quantitative research published in Brazilian journals. In contrast, papers in top journals explore a greater variety of analytical techniques to approach strategy phenomena. Whereas the ordinary least squares method requires a metric variable as dependent variable, logit and probit models use a binary, non-metrical variable as the dependent variable, which allows the researcher to investigate membership phenomena. Zypher (2009) argued that when researchers are thinking about research design and statistical techniques, they should switch their usual mindset - a regression researcher should think as a structural equation researcher and vice-versa, to evaluate the technique with the best fit for the research design and to assure that the collected data has been properly gathered. The same exercise can be done by Brazilian researchers, in particular by qualitative researchers thinking about how the usual qualitative study can be performed by quantitative researchers. Evaluating which alternative offers the best result in terms of building theory and communicating the idea can increase not only the methodological quality of papers but also the creativity for new theoretical advances.

\section{(Figure 4.2)}

SUMMARY OF QUANTITATIVE METHODS OF PAPERS IN STRATEGY

\begin{tabular}{lllll}
\hline & \multicolumn{3}{c}{ Brazilian Journals } & \multicolumn{2}{c}{ Top Journals } \\
\cline { 2 - 5 } & $2006-2010$ & $2011-2015$ & $2006-2010$ & $2011-2015$ \\
\hline Experiment/Quasi & $0(0 \%)$ & $0(0 \%)$ & $10(2 \%)$ & $27(5 \%)$ \\
\hline experiment/quasi experiment & 0 & 0 & 5 & 15 \\
\hline Simulation & 0 & 0 & 5 & 12 \\
\hline Field study with primary data & $24(61 \%)$ & $29(61 \%)$ & $124(31 \%)$ & $106(20 \%)$ \\
\hline Survey & 24 & 29 & 124 & 106 \\
\hline
\end{tabular}




\section{(Figure 4.2 (continuation))}

SUMMARY OF QUANTITATIVE METHODS OF PAPERS IN STRATEGY

\begin{tabular}{|c|c|c|c|c|}
\hline & \multicolumn{2}{|c|}{ Brazilian Journals } & \multicolumn{2}{|c|}{ Top Journals } \\
\hline & $2006-2010$ & $2011-2015$ & $2006-2010$ & $2011-2015$ \\
\hline Field study with secondary data & $15(38 \%)$ & 18(38\%) & $273(67 \%)$ & $388(75 \%)$ \\
\hline archival/event & 9 & 15 & 256 & 366 \\
\hline case study & 4 & 1 & 13 & 15 \\
\hline bibliometric/scientometrics & 2 & 1 & 2 & 1 \\
\hline meta-analysis & 0 & 1 & 2 & 5 \\
\hline other & 0 & 0 & 0 & 1 \\
\hline \multicolumn{5}{|l|}{ Number of source } \\
\hline Single & $29(75 \%)$ & $34(73 \%)$ & $275(68 \%)$ & $326(63 \%)$ \\
\hline Multiple & $10(25 \%)$ & $13(27 \%)$ & $132(32 \%)$ & 195(37\%) \\
\hline \multicolumn{5}{|l|}{ Data source } \\
\hline Self-reported & $25(64 \%)$ & $30(63 \%)$ & $127(31 \%)$ & $113(21 \%)$ \\
\hline Observation & $1(2 \%)$ & $\mathrm{O}(0 \%)$ & $1(0 \%)$ & $2(0 \%)$ \\
\hline Interview & $2(5 \%)$ & $4(8 \%)$ & $16(3 \%)$ & $20(4 \%)$ \\
\hline Database & $16(41 \%)$ & 18(38\%) & $272(67 \%)$ & $390(75 \%)$ \\
\hline Company report & $8(20 \%)$ & $5(10 \%)$ & $24(6 \%)$ & $25(5 \%)$ \\
\hline Other & $1(2 \%)$ & $3(6 \%)$ & $15(3 \%)$ & $23(5 \%)$ \\
\hline \multicolumn{5}{|l|}{ Data analysis } \\
\hline Descriptive & 6 & 1 & 0 & 0 \\
\hline Correlation & 1 & 3 & 3 & 2 \\
\hline Analysis of variance & 7 & 4 & 19 & 19 \\
\hline Regression & 8 & 23 & 339 & 450 \\
\hline Chi-square & 2 & 1 & 3 & 0 \\
\hline Discriminant and cluster & 7 & 5 & 4 & 1 \\
\hline Network analysis & 1 & 2 & 5 & 9 \\
\hline Structural equation modeling/path analysis & 5 & 10 & 26 & 21 \\
\hline
\end{tabular}




\begin{tabular}{|c|c|c|c|c|}
\hline & \multicolumn{2}{|c|}{ Brazilian Journals } & \multicolumn{2}{|c|}{ Top Journals } \\
\hline & 2006-2010 & 2011-2015 & $2006-2010$ & $2011-2015$ \\
\hline Time series & 1 & 0 & 6 & 5 \\
\hline Other & 1 & 0 & & 12 \\
\hline \multicolumn{5}{|l|}{ Regression model } \\
\hline Logit & 0 & 1 & 55 & 74 \\
\hline Generalized method of moments & 0 & 1 & 5 & 15 \\
\hline Negative Binomial & 0 & 0 & 24 & 28 \\
\hline Poisson & 0 & 0 & 10 & 12 \\
\hline Generalized Least Squares & 0 & 0 & 19 & 11 \\
\hline Ordinary least squares & 2 & 9 & 80 & 87 \\
\hline Two-stage least squares & 0 & 2 & 13 & 19 \\
\hline Hazard model/ Weibull/cox proportional hazard & 0 & 0 & 13 & 25 \\
\hline Hierarchical modeling/ Multilevel analysis & 1 & 0 & 43 & 40 \\
\hline Probit & 2 & 1 & 18 & 40 \\
\hline Tobit & 0 & 0 & 16 & 16 \\
\hline Other & 0 & 1 & 12 & 23 \\
\hline
\end{tabular}

Source: Elaborated by the authors.

In terms of qualitative methods, we found no difference between strategy papers $\chi^{2}=(1, N=226)=3.764 p=.052$, data sources $\chi^{2}=(1, N=226)=$ $=1.232 p=.267$, and analytical techniques $\chi^{2}=(4, N=166)=6.721 p=.151$. Case study with multiple sources, including interview and archives, database or company reports, and with content analysis was the main design among papers. Nevertheless, they differed in one critical aspect. Brazilian papers are predominantly deductive case studies whereas those in five top journals are inductive. Why does the difference matter? Deductive case studies describe the fit between a theoretical framework and the case which has limited potential to generate any theoretical contribution, especially if it employs only one theory. On the other hand, inductive case studies build a new concept or explain gaps in the current knowledge. 


\section{(Figure 4.3)}

SUMMARY OF QUALITATIVE METHODS OF PAPERS IN STRATEGY

\begin{tabular}{|c|c|c|c|c|}
\hline & \multicolumn{2}{|c|}{ Brazilian Journals } & \multicolumn{2}{|c|}{ Top Journals } \\
\hline & $2006-2010$ & $2011-2015$ & $2006-2010$ & $2011-2015$ \\
\hline Field study with primary data & $50(94 \%)$ & $81(93 \%)$ & $28(84 \%)$ & $45(86 \%)$ \\
\hline Survey & 0 & 1 & 0 & 0 \\
\hline action research & 2 & 0 & 0 & 0 \\
\hline Ethnography & 0 & 1 & 1 & 1 \\
\hline case study & 47 & 78 & 26 & 44 \\
\hline Other & 1 & 1 & 1 & 0 \\
\hline Field study with secondary data & $3(6 \%)$ & $6(7 \%)$ & $5(16 \%)$ & $7(14 \%)$ \\
\hline History & 1 & 2 & 2 & 2 \\
\hline archival/event & 1 & 0 & 1 & 3 \\
\hline case study & 0 & 1 & 1 & 0 \\
\hline bibliometric/scientometric & 1 & 3 & 1 & 2 \\
\hline \multicolumn{5}{|l|}{ Number of source } \\
\hline Single & 10(19\%) & $20(23 \%)$ & $6(18 \%)$ & $7(14 \%)$ \\
\hline Multiple & $43(81 \%)$ & $67(77 \%)$ & $27(82 \%)$ & $45(86 \%)$ \\
\hline \multicolumn{5}{|l|}{ Data Source } \\
\hline Self-reported & $6(11 \%)$ & $6(7 \%)$ & $1(3 \%)$ & $1(2 \%)$ \\
\hline Observation & $16(30 \%)$ & $27(31 \%)$ & $17(52 \%)$ & $22(42 \%)$ \\
\hline Interview & $47(89 \%)$ & $78(90 \%)$ & 28(85\%) & $41(79 \%)$ \\
\hline Database & $13(26 \%)$ & $23(27 \%)$ & $12(36 \%)$ & $30(58 \%)$ \\
\hline company report & $21(40 \%)$ & $28(32 \%)$ & $9(27 \%)$ & $10(20 \%)$ \\
\hline Other & $2(4 \%)$ & $3(3 \%)$ & $9(27 \%)$ & $8(15 \%)$ \\
\hline \multicolumn{5}{|l|}{ Data analysis } \\
\hline Content Analysis & 30 & 51 & 21 & 28 \\
\hline Discursive Analysis & 2 & 5 & 2 & 6 \\
\hline Narrative Analysis & 0 & 5 & 3 & 6 \\
\hline Comparative methods - QCA, DFA & 0 & 2 & 2 & 2 \\
\hline Other & 8 & 4 & 2 & 6 \\
\hline Not reported & 13 & 20 & 1 & 4 \\
\hline
\end{tabular}


These findings strengthen the discussion started by Bertero et al. (2003) and Rossoni et al. (2010), that most papers in Brazil employ case study not as tool to develop new ideas with the proper rigor that the method requires, but as mere exemplification of singular cases. Moreover, it is possible that such issue occurs due to the short duration of graduate courses. The short period that academics have to conclude their research leads them to prioritize cross-sectional research (Figure 4.1), which, in turn, does not provide enough time to deepen their studies theoretically and methodologically. This historical pattern may reflect consequently in a lower effort to advance the knowledge in the Brazilian academic field.

Moreover, this scenario serves to increase the difference between Brazilian papers and top journals papers given that usually the cases adopted have little relevance in a broader context. Studies investigating specific, and frequently non-relevant organizations, contribute neither internationally nor nationally to the field as a whole. Therefore, it partially helps to explain why Brazilian papers tend to ground their studies in Anglo-Saxon research (Schneider et al., 2009).

Thus far, we have described and pointed out the differences between Brazilian papers and paper in five top journals, and although we have identified possible reasons and ways to overcome these differences, a critical point was not fully elaborated. Considering all points described previously, we defend the notion that overall the drivers motivating Brazilian papers and top-five journals papers are unequal, reflecting on methodological procedures. Colquitt and Zapata-Phelan (2007) proposed that every paper can be analyzed in two dimensions: the level of building theory (from attempts to replicate previous effects to examine a previously unexplored relationship or process) and the level of testing theory (is inductive or grounds prediction with logical speculation to grounds predictions with existing theories). Using two dimensions, they created five kinds of papers. For our purposes only three matter: builders, testers, and expanders. Builders are studies focused on proposing new constructs, relationships or processes; testers test hypotheses of well-established theories; and expanders theorize new constructs, relationships or processes while they submit current theories to test empirically. Given that Brazilian papers principally utilize deductive qualitative case studies, cross-sectional design, descriptive statistics and few kinds of regression, we characterized those on average as testers - the focus is to test whether theories developed in a different context fit with Brazilian reality. On the other hand, papers in top journals were essentially expanders because of the high degree of pressures the journals had to accept only papers with original theoretical contribution. 
Is it desirable to move from testers to expanders? Is it possible even without access to resources such as large structured databases? In our view, the answer is yes to both questions. A recurrent claim on bibliometric studies is the necessity to create theories adjusted to the Brazilian context (Vergara \& Carvalho, 1995; Schneider et al., 2009). To accomplish this goal, we need to minimize the methodological differences described before. Inductive case studies and quantitative research, using public but still not compiled data, comprise the first step not only to increase the quality of research but also to organize and to create a set of theories and body of evidence from the Brazilian context. To overcome a possible problem of sample size, for instance, researchers can use experiments and quasi-experiments to deliver theoretical contributions describing and explaining causal mechanisms associated with theories in strategy. Because they focus on causal links, experiments and quasi-experiments require a smaller sample size than field studies (see Chatterji, Findley, Jensen, Meier, \& Nielson, 2016). Simulation experiments are another possibility. They can test temporal dynamics and interaction effects on controlled environments (see Fioretti, 2013). On the qualitative side, the use of inductive case studies or comparative analysis such as fuzzy set (see Fiss, 2011) represents viable alternatives to current methods. Additionally, we can use the different context (the Brazilian context) not only to assess the fit of theoretical framework but also to create unexpected breakdowns between theory and empirical context, exploring them to refine the relationship or process among variables (see Alvesson \& Sandberg, 2011).

\subsection{Robustness check}

The chi-square test of independence performed in the last section to verify the association between methodological profiles and Brazilian journals and top journals is influenced by the sample size. The Strategic Management Journal represents around $70 \%$ of our sample and its overall methodological profile is statistically different from other top journals, $\chi^{2}=(2, N=1084)=$ 105.716, $\mathrm{p}<.001$, meaning our results could be biased by the Strategic Management Journal methodological profile. Hence, we performed the same chi-square test of independence on the last section without papers from Strategic Management Journal. Overall, our results remained consistently the same. The only noticeable difference occurred in the comparison of research designs in the period of 2006 to 2010. The statistically significant chi-square test of independence became insignificant, $\chi^{2}=(2, N=136)=$ 
$5.500, p=.064$. This means that when we exclude Strategic Management Journal papers from the test, the research designs applied in the top journals were not different those in Brazilian Journals. However, the test of the period of 2011-2015 was still significant, the $\chi^{2}=(2, N=177)=12.68, p=.002$. Unfortunately, it positively supports our argumentation that the methodological difference between the research designs applied is increasing.

\section{CONCLUSION}

Based on a systematic review, our research promotes a methodological comparison between Brazilian papers and papers in five top journals in the strategy field. Besides presenting a summary and a comparison of the scenario identified, our study also presents some implications from the results that we expect may contribute to the advancement of the Brazilian academic strategy field and to overcome the differences discussed.

Among the main findings, we identified significant differences in proportion to the research design, with a lower preference for quantitative methods in Brazil. Not only do Brazilian papers use less quantitative methods, but also those that employ them tend to do it with less rigor and less refinement as compared to top journal papers. The differences between the mean of the sample, time frame and data analysis procedures exemplify this.

Whereas the majority of Brazilian papers are based on survey research and descriptive statistical analysis and correlation, in the top international journals there is a preference for studies based on archival/event studies. Such attributes provide the possibility of using a larger range of data, tests and statistics models in the analysis process with, consequently, a better robustness concerning the hypothesis test.

What is more, as Brazilian papers are mainly based on qualitative research with primary data, they mainly favor cross-sectional research rather than longitudinal ones. In the same vein, time frame is probably linked to the evaluation process of Brazilian post-graduate courses and the mindset of their students, studies being predominantly conducted under a clear concern to finish the program inside the available timeframe, which is 24 months for a master's degree and 48 months for a doctoral degree. Consequently, theses based on a cross-sectional framework of research, more than those based on a longitudinal one, are more adequate. In contrast, in North America, for instance, only funding is restricted to 48 months, yet the research program expects that the student finish in 48 months. 
Also, concerning qualitative papers based on case study as a research strategy, although we did not find significant differences between Brazilian and international papers, we noticed that most Brazilian case studies express a deductive logic while international case studies are predominantly inductive. This impacts the possibility of generalizing the findings of the research. In other words, it means that nationally the case studies are conducted not as an epistemological form of accumulating observations but as a substitute for experimental testing of theoretical propositions.

Therefore, our study reinforces some results found by other studies, concerning qualitative studies and the necessity of maturation and development of the strategy field in Brazil in comparison to the international field (Bertero et al., 2003; Rossoni et al., 2010). It does not mean relying exclusively on other contexts, but, by contrast, developing knowledge that adapts to the Brazilian context (Vergara \& Carvalho, 1995; Schneider et al., 2009) and simultaneously provides theoretical contributions. By seeking to do this, Brazilian researchers will move from testing developed theories through different example cases to expanding actual knowledge through original theoretical contributions.

As pointed by Aguinis et al. (2009), organizational science researches have their own methodological comfort zones which make change usually difficult and effortful. However, since theoretical advancements are not possible without better and improved methodological tools, the findings here drawn contribute to the goal of strategic management scholars becoming more knowledgeable about these aspects and to strategy science moving forward.

Finally, our study also has its limitations. First, the research designs that appeared in top journals were not immune to criticism. On the contrary, deep qualitative reviews assessing only a small fraction of research designs have identified methodological limitations in those works, in issues such as moderators and mediation (Aguinis, Edwards, \& Bradley, 2016), structural equation modeling (Williams, Gavin, \& Hartman, 2004), the use of logit and probit models (Hoetker, 2007) and sampling (Short, Ketchen, \& Palmer, 2002). Second, our paper did not include papers published in conferences, which in Brazil is still an important way of publication for research results, even in strategy. Notwithstanding these, we believe that our study contributes to the discussion and serves to highlight the differences between Brazilian publications and publications in some of the top management journals, in order to guide further research forward to the development and advancement of the field of strategy. Developing better methodological procedures is 
necessary to improve good theory in the scientific domain. Therefore, by mapping the field, we have highlighted some aspects that make evident some limitations and lack of contribution, and simultaneously we have cast light on some future possibilities of evolution.

\section{AVALIANDO AS DIFERENÇAS METODOLÓGICAS ENTRE PERIÓDICOS BRASILEIROS E TOP JOURNALS EM ESTRATÉGIA}

\section{) RESUMO}

Objetivo: Nosso estudo compara os procedimentos metodológicos de artigos brasileiros com os de trabalhos publicados na AMJ, OS, ASQ, JMS e SMJ no campo de estratégia, de 2006 a 2015.

Originalidade/valor: Nosso estudo (a) identifica e descreve diferenças metodológicas, oferecendo uma referência para aprimorar estudos futuros; (b) inicia uma discussão sobre as razões pelas quais essas diferenças existem e suas implicações no avanço do campo de estratégia; e (c) sugere formas de superar as restrições atuais e melhorar a qualidade de nossa pesquisa.

Design/metodologia/abordagem: Com base em uma revisão sistemática, analisamos dez periódicos brasileiros com maior fator de impacto e cinco top journals. A pesquisa gerou uma amostra final de 1294 artigos empíricos. Os dados foram analisados por meio da análise de conteúdo, pela qual nosso esquema de codificação continha três dimensões: design de pesquisa, medida e abordagem analítica.

Resultados: Encontramos algumas diferenças metodológicas que podem caracterizar os artigos brasileiros como testadores e os top journals como expansores, reforçando os resultados encontrados por outros estudos quanto à necessidade de desenvolver o campo da estratégia no Brasil para ser mais competitivo com o campo internacional em geral. Portanto, concluímos que é desejável melhorar nossos métodos de pesquisa como um campo e, possível superar as diferenças metodológicas, ajudando não apenas a desenvolver teorias, mas também a considerar a realidade brasileira. 


\section{PALAVRAS-CHAVE}

Métodos de pesquisa. Quantitativo. Qualitativo. Análise de dados. Campo de estratégia.

\section{$\int$ REFERENCES}

Aguinis, H., \& Vandenberg, R. J. (2014). An ounce of prevention is worth a pound of cure: Improving research quality before data collection. Annual Review of Organizational Psychology and Organizational Behavior, 1(1), 569595. doi:10.1146/annurev-orgpsych-031413-091231

Aguinis, H., Edwards, J. R., \& Bradley, K. J. (2016). Improving our understanding of moderation and mediation in strategic management research. Organizational Research Methods, 20(4), 1-21. doi:10.1177/10 94428115627498

Aguinis, H., Pierce, C. A., Bosco, F. A., \& Muslin, I. S. (2009). First decade of organizational research methods: Trends in design, measurement, and data-analysis topics. Organizational Research Methods, 12(1), 69-112. doi:10. $1177 / 1094428108322641$

Alvesson, M., \& Sandberg, J. (2011). Generating research questions through problematization. Academy of Management Review, 36 (2), 247-271. doi:10.54 65/amr.2009.0188

Baruch, Y., \& Holtom, B. C. (2008). Survey response rate levels and trends in organizational research. Human relations, 61(8), 1139-1160. doi:10.11 77/0018726708094863

Bergh, D. D. (2003). Thinking strategically about contribution. Academy of Management Journal, 46(2), 135-136. doi:10.5465/amj.2003.17481820

Bertero, C. O., Vasconcelos, F. C. de, \& Binder, M. P. (2003). Estratégia empresarial: A produção científica brasileira entre 1991 e 2002. Revista de Administração de Empresas, 43 (4), 48-62.

Bono, J. E., \& McNamara, G. (2011). Publishing in AMJ-part 2: Research design. Academy of Management Journal, 54(4), 657-660. doi:10.5465/amj. 2011.64869103

Chatterji, A. K., Findley, M., Jensen, N. M., Meier, S., \& Nielson, D. (2016). Field experiments in strategy research. Strategic Management Journal, 37(1), 116-132. doi:10.1002/smj.2449 
Clark, L. A., \& Watson, D. (1995). Constructing validity: Basic issues in objective scale development. Psychological Assessment, 7(3), 309. doi:10. 1037/1040-3590.7.3.309

Colquitt, J. A., \& Zapata-Phelan, C. P. (2007). Trends in theory building and theory testing: A five-decade study of the Academy of Management Journal. Academy of Management Journal, 50(6), 1281-1303. doi:10.5465/ amj.2007.28165855

Conway, J. M., \& Lance, C. E. (2010). What reviewers should expect from authors regarding common method bias in organizational research. Journal of Business and Psychology, 25(3), 325-334. doi:10.1007/s10869-010-9181-6

Cools, E., Armstrong, S. J., \& Verbrigghe, J. (2014). Methodological practices in cognitive style research: Insights and recommendations from the field of business and psychology. European Journal of Work and Organizational Psychology, 23(4), 627-641. doi:10.1080/1359432X.2013.788245

Durand, R., Grant, R., \& Madsen, T. (2017). The expanding domain of strategic management research and the quest for integration. Strategic Management Journal, 38(4), 4-16. doi:10.1002/smj.2607

Duriau, V. J., Reger, R. K., \& Pfarrer, M. D. (2007). A content analysis of the content analysis literature in organization studies: Research themes, data sources, and methodological refinements. Organizational Research Methods, 10(1), 5-34. doi:10.1177/1094428106289252

Fioretti, G. (2013). Agent-based simulation models in organization science. Organizational Research Methods, 16(2), 227-242. doi:10.1177/109442811 2470006

Fiss, P. C. (2011). Building better causal theories: A fuzzy set approach to typologies in organization research. Academy of Management Journal, 54(2), 393-420. doi:10.5465/amj.2011.60263120

Green, J. P., Tonidandel, S., \& Cortina, J. M. (2016). Getting through the gate: Statistical and methodological issues raised in the reviewing process. Organizational Research Methods, 19(3), 402-432. doi:10.1177/109442811 6631417

Guerras-Martín, L. Á., Madhok, A., \& Montoro-Sánchez, Á. (2014). The evolution of strategic management research: Recent trends and current directions. Business Research Quarterly, 17(2), 69-76. doi:10.1016/j.brq. 2014.03.001

Hoetker, G. (2007). The use of logit and probit models in strategic management research: Critical issues. Strategic Management Journal, 28(4), 331-343. doi:10.1002/smj.582 
Johnson, R. E., Rosen, C. C., \& Djurdjevic, E. (2011). Assessing the impact of common method variance on higher order multidimensional constructs. Journal of Applied Psychology, 96(4), 744. doi:10.1037/a0021504

Ketchen Jr., D. J., Boyd, B. K., \& Bergh, D. D. (2008). Research methodology in strategic management: Past accomplishments and future challenges. Organizational Research Methods, 11(4), 643-658. doi:10.1177/109442810 8319843

Kühl, M. R., \& Kühl, C. A. (2011). Tecnologia nos estudos da estratégia. Revista de Administração da Unimep, 9(2), 87-107.

Leal, P. C. R., Oliveira, J. de, \& Soluri, F. A. (2003). Perfil da pesquisa em finanças no Brasil. Revista de Administração de Empresas, 43(1), 1-14. doi:10. 1590/S0034-75902003000100010

MacKenzie, S. B., Podsakoff, P. M., \& Podsakoff, N. P. (2011). Construct measurement and validation procedures in MIS and behavioral research: Integrating new and existing techniques. MIS quarterly, 35(2), 293-334. doi:10.2307/23044045

Mahoney, J. T., \& McGahan, A. M. (2006). The field of strategic management within the evolving science of strategic organization. Strategic Organization, 5(1), 79-99. doi:10.1177/1476127006074160

Oliveira, D. de, Walter, S. A., \& Bach, T. M. (2012). Critérios de validade em pesquisas em estratégia: Uma análise em artigos publicados no EnAnpad de 1997 a 2010. Revista de Administração Mackenzie, 13(6), 225-254. doi:10.1590/S1678-69712012000600010

Podsakoff, P. M., MacKenzie, S. B., Lee, J. Y., \& Podsakoff, N. P. (2003). Common method biases in behavioral research: A critical review of the literature and recommended remedies. Journal of applied psychology, 88(5), 879. doi:10.1037/0021-9010.88.5.879

Ronda-Pupo, G. A., \& Guerras-Martin, L. Á. (2012). Dynamics of the evolution of the strategy concept 1962-2008: A co-word analysis. Strategic Management Journal, 33(2), 162-188. doi:10.1002/smj.948

Rossoni, L., \& Guarido Filho, E. R. (2009). Cooperação entre programas de pós-cooperação entre programas de pós-graduação em graduação em Administração no Brasil: Evidências estruturais em quatro áreas temáticas. Revista de Administração Contemporânea, 13(3), 366-390. doi:10.1590/ S1415-65552009000300003

Rossoni, L., \& Guarido Filho, R. (2007). Cooperação interinstitucional no campo da pesquisa em estratégia. Revista de Administração de Empresas, 47(4), 1-15. doi:10.1590/S0034-75902007000400007 
Rossoni, L., Guarido Filho, E. R., Francisconi, K., \& Albuquerque Filho, J. B. (2010). Cooperação, estratificação e perfil da pesquisa em estratégia no Brasil. Revista Eletrônica de Ciência Administrativa, 9(2), 181. doi:10.5329/ RECADM.20100902005

Saraiva, E. V., \& Carrieri, A. D. P. (2009). Citações e não citações na produção acadêmica de estratégia no Brasil: uma reflexão crítica. Revista de Administração da USP, 44(2), 158-166.

Scandura, T. A., \& Williams, E. A. (2000). Research methodology in management: Current practices, trends, and implications for future research. Academy of Management Journal, 43(6), 1248-1264. doi:10.5465/1556348

Schneider, A. B., Carneiro, M. L., Serra, F. A. R., \& Ferreira, M. P. (2009). Estratégia competitiva: Michael Porter 30 anos depois. Revista de Administração da UFSM, 2(2), 298-326. doi:10.5902/198346591558

Schneider, L. C. (2013). Pensamento estratégico organizacional: Origens, evolução e principais Influências. Paper presented at the meeting of Anpad, Bento Gonçalves, 2013.

Short, J. C., Ketchen Jr., D. J., \& Palmer, P. B. (2002). The role of sampling in strategic management research on performance: A two-study analysis. Journal of Management, 28(3), 363-385. doi:10.1016/S0149-2063(02)00 132-0

Vergara, S. C., \& Carvalho Jr., D. D. S. (1995). Nacionalidade dos autores referenciados na literatura brasileira sobre organizações. Revista Brasileira de Administração Contemporânea, 1(6), 169-188. doi:10.1590/S1415655 52001000500006

Vieira, G. D. F. (2003). Narciso sem espelho: A publicação brasileira de marketing. Revista de Administração de Empresas, 43(1), 1-10. doi:10.15 90/ S0034-75902003000100009

Walter, S. A., Bach, T. M., Lanza, B. B. B., \& Sato, K. H. (2013). Scientific Publication in the Area of Strategy Enanpad and 3es: from 1997 to 2010. Iberoamerican Journal of Strategic Management, 12(2), 69-104. doi:10.5585/ riae.v12i2.1837

Williams, L. J., Gavin, M. B., \& Hartman, N. S. (2004). Structural equation modeling methods in strategy research: Applications and issues. In D. J. Ketchen \& D. D. Bergh (Eds.), Research methodology in strategy and management. Oxford, UK: Elsevier, pp. 303-346.

Zhang, Y. A., \& Shaw, J. D. (2012). Publishing in AMJ-Part 5: Crafting the methods and results. Academy of Management Journal, 55(1), 8-12. doi:10.5465/amj.2012.4001 
Zypher, M. J. (2009). When mindsets collide: Switching analytical mindsets to advance organization science. Academy of Management Review, 34(4), 677-688. doi:10.5465/amr.34.4.zok677

\section{(APPENDIX A)}

Given our goal to compare a representative sample of overall quality of methodological procedures in Brazilian strategy research to the methodological procedures in the papers published in top strategy journals, the possibility that the best Brazilian research was published internationally is a threat that could potentially bias our comparison. Thus, to evaluate whether our sample is a valid proxy of the true overall quality of Brazilian research, we assessed the potential of bias in our sample-in other words, how often Brazilian scholars have published internationally.

First, using CAPES data on the intellectual production of graduate programs from 2013 to 2016 in Brazil, we calculated the proportion of occurrences of 1. top 50 journals, and 2. papers written in English that were not published in Brazilian journals. The CAPES dataset is compiled from the data filled out by graduate programs during the evaluation process. Thus, our assumption is that if Brazilian researchers are consistently publishing their "best" research internationally, it will show up in the CAPES dataset. CAPES records occurrence by researcher and not by paper. One paper, for example, which has three coauthors, appears three times in the dataset. Each occurrence has institution, field of program, year, language of publication, and journal title.

The prevalence of the top 50 management journals, by Journal of Citations Reports (26\% of total of journals in Management category), is $.53 \%$ (124). Because this number is downward biased by the fact that we cannot separate the strategy field from other fields inside of management, we calculated the occurrence of English papers that are not published in Brazilian journals, $14.16 \%$ (3308). This is a very conservative measure given that we are not controlling for journal quality. Both measures do not indicate that Brazilian scholars, on average, reach international journals, which could bias our sample and comparison.

Second, we verified the possibility of bias by checking the proportion of Brazilian publications in a subset of authors of our dataset. This improves 
chances of obtaining evidence of a relationship because we cannot sort CAPES dataset by strategy authors and by paper. We have 587 Brazilian authors in our dataset. From that, we randomly selected $50 \%$ of authors. From each author, we accessed the curriculum lattes and counted the total number of publications from 2006 to 2015 (the same timeframe of our sample) and the proportion of Brazilian publications. Our expectation is that if authors publish frequently internationally, then the proportion of papers in Brazilian journals will be low. We established as null hypothesis a proportion of $75 \%$ or less Brazilian publications. This hypothesis means that if the author has 4 projects, the author will publish at least one (the best) project in an English journal, generating a ratio of 1:3.

The average number of Brazilian publications was $90.47 \%$, and the standard deviation was $13.24 \%$. We performed a one-sample t-test to evaluate whether we could reject the null hypothesis. We also tested by period (20062010, 2011-2015) separately. Finally, the result could be upward biased because of less productive scholars and one-timers authors. Thus, we performed the three tests again but using only scholars who have ten or more publications. Figure A1 summarizes the statistical results. In all scenarios, we found evidence to reject the null hypothesis. In the last scenario, the result is similar to the $14.16 \%$ that we found using the CAPES dataset.

\section{(Figure A1)}

\section{RESULTS OF ONE-SAMPLE T-TEST AND DESCRIPTIVE STATISTICS FOR PROPORTION OF BRAZILIAN PUBLICATIONS}

\begin{tabular}{lccccccccc}
\hline \multicolumn{1}{c}{ Outcome } & M & SD & $\mathrm{n}$ & $\begin{array}{c}\text { Comparison } \\
\text { Value }\end{array}$ & $\begin{array}{c}95 \% \mathrm{Cl} \\
\text { for Mean } \\
\text { Difference }\end{array}$ & $\mathrm{t}$ & $\mathrm{p}$ & df \\
\hline Overall Proportion & 90.47 & 13.25 & 296 & 75 & $13.95,16.98$ & 20.08 & $<.001$ & 295 \\
\hline Proportion (2006-2010) & 94.25 & 14.22 & 262 & 75 & $17.52,20.98$ & 21.91 & $<.001$ & 261 \\
\hline Proportion (2011-2015) & 86.60 & 18.00 & 271 & 75 & $9.45,13.76$ & 10.61 & $<.001$ & 270 \\
\hline Overall Proportion >10 & 88.97 & 12.74 & 194 & 75 & $12.17,15.77$ & 15.27 & $<.001$ & 193 \\
\hline Proportion (2006-2010) > 10 & 94.24 & 11.94 & 186 & 75 & $17.51,20.97$ & 21.96 & $<.001$ & 185 \\
\hline Proportion (2011-2015) > 10 & 84.95 & 17.47 & 194 & 75 & $7.47,12.42$ & 7.93 & $<.001$ & 193 \\
\hline
\end{tabular}

Source: Elaborated by the authors.

Finally, using only the sample of scholars who have more than 10 publications, we performed a paired-samples t-test to identify if the difference 
in means found in previously test was significant. There was a significant difference in the scores for the proportion of Brazilian publications with more than 10 publications at Time $1(\mathrm{M}=94.24, \mathrm{SD}=11.94)$ and at Time 2 $(\mathrm{M}=84.95, \mathrm{SD}=17.47) ; \mathrm{t}(-8.01), \mathrm{p}<.05$. It means that Brazilian scholars are indeed moving to publish in international journals, but it happens less often and has fewer implications for our study than predicted.

Following our use of the CAPES dataset and our authors test, we conclude that examining articles published in Brazilian journals serves as a valid proxy of the true overall quality of Brazilian research.

\section{AUTHOR NOTE}

Ronei da S. Leonel, Business Administration, Universidade Federal do Paraná; Sara F. Picheth, Business Administration, Universidade Estadual de Maringá; Fernanda R. da Silva, Business Administration, Universidade Estadual de Maringá, João M. Crubellate, Business Administration, Fundação Getúlio Vargas.

Ronei da S. Leonel is now a Ph.D. Student at University of Memphis; Sara F. Picheth is now a Ph.D. Candidate at Universidade Estadual de Maringá.

Correspondence concercing this article should be adressed to Fernanda R. da Silva, Rua Sete de Setembro, 442, Centro, Palmital, SP, São Paulo, Brazil, CEP 19.970-000.

E-mail: frsilva.prof@gmail.com

EDITORIAL BOARD

Editor-in-chief

Silvio Popadiuk

Associated Editor

Thais Vick

(iD) https://orcid.org/0000-0003-4869-7612

Technical Support

Vitória Batista Santos Silva
EDITORIAL PRODUCTION

Publishing Coordination
Irina Migliari
Editorial Trainee
Maria Luiza Vanz
Copyeditor
Irina Migliari

Language Editor Daniel Leão

Layout Designer Emap

Graphic Designer Libro 